\title{
Alleviating Salinity Stress During Seed Germinating by Priming Techniques : A Review
}

\author{
Sandhya R Verma ${ }^{1 *}$, Dr. Hitesh A Solanki ${ }^{2}$ \\ ${ }^{* 1}$ Department of Botany, Bio-informatics, Climate change impact Management, USSC, Gujarat University, Ahmedabad, \\ Gujarat, India \\ ${ }^{2}$ Department of Botany, Bio-informatics, Climate change impact Management, USSC, Gujarat University, Ahmedabad, \\ Gujarat, India
}

\begin{abstract}
Article Info

Volume 8, Issue 2

Page Number : 198-202

Publication Issue

March-April-2021

\section{Article History}

Seed germination and seedling growth are the two critical stages for crop establishment. These stages are the most sensitive to abiotic stresses, which decreases the germination percentage and increases germination time. Due to such abiotic stress, the germination of crop fails in adverse conditions. Salinity is one of the major abiotic stress, which adversely affects almost every aspect of the plant's physiology, biochemistry and decreases yield. Salinity is the most severe threat to agriculture and major environmental factors that limit crop growth and productivity. Various techniques have been shown to improve emergence and stand establishment under salt stress. One of the most frequently utilized technique is seed priming. The seed priming process deals with the prior exposure of abiotic stress, making a seed more resistant to future exposure. Seed priming stimulates pre-germination metabolic activities and enhances radicle protrusion. It enhances the antioxidant defense system and the repair of membranes. The process of seed priming and the mechanism of the effect of salinity on seed germination have been discussed. The physiological, biochemical, and molecular changes induced by priming leading to seed enhancement have also been covered.
\end{abstract}

Accepted : 01 March 2021

Published : 04 March 2021
Keywords: Seed Germination, Salt Stress, Seed Priming, Antioxidant Defense System

\section{INTRODUCTION}

The crop production depends on the quality of seed, which demands each seed to be readily germinable and produce a vigorous seedling for higher yield (Suruthi, Sujathal \& Menaka, 2019). As a seed is a fundamental factor in crop production, optimum seed germination is the key to good stand establishment (Tania et al., 2020). Due to unfavorable growth conditions such as salinity, the percentage of seed germination, emergence, and vigor has been adversely affected. This adverse event could lead to crop failure. However, salt-stress effects on crops depend on the concentration, time of exposure to salt, plant

Copyright: (C) the author(s), publisher and licensee Technoscience Academy. This is an open-access article distributed under the terms of the Creative Commons Attribution Non-Commercial License, which permits unrestricted non-commercial use, distribution, and reproduction in any medium, provided the original work is properly cited 
genotype, and environmental factors (Alves et al., 2019). There are various seed enhancement technologies available to enhance seed germination in such type of unfavourable environmental conditions. Seed priming is one of the most straightforward technique which acts as an effective measure to good stand establishment under abiotic stresses. Seed priming is a pre-sowing treatment that can improve seed germination and performance and tolerate abiotic stress (Anwar A et al., 2020).

Seed priming techniques often provide rapid synchronized seed germination, leading to enhanced crop yield and reducing the use of fertilizers (Pawar \& Laware, 2018).

\section{THE PHENOMENON OF SEED PRIMING}

"Seed priming is a pre-sowing treatment given to the seeds which allow uptake of water to initiate early germination events but does not permit radicle protrusion, followed up by drying" (Powell \& Matthews, 1988; Donald, 2000). Priming promotes germination under three phases' imbibition, germination, and growth. Phase I is imbibition, which is rapid in which proteins are synthesized, DNA, and mitochondria are repaired using existing mRNA. Phase II is the lag phase called the activation phase, where the minimal net gain of water occurs for metabolic activities, including the synthesis of proteins and mitochondria from new mRNA. The final phase, i.e., phase III, involves more water uptake coupled with radicle elongation (Bradford, 1995). Phase II is the critical phase in germination as it is much sensitive to environmental factors than the third phase (Come \& Thevenot, 1982). Priming allows phase I and phase II but does not allow seeds to enter the last phase. Hence, it is sufficient to initiate pregerminative metabolic activities but insufficient for radicle protrusion (Bradford, 1986).

Phase I and II are the foundations of priming; the primed seeds have passed through the second critical phase hence primed seeds could germinate under the unfavorable condition as compared to unprimed ones (Corbineau \& Come, 2006).

\section{METHODS OF SEED PRIMING}

There are various techniques of seed priming, broadly classified into conventional and advanced methods. The conventional techniques include hydro-priming, halo-priming, osmo-priming, bio-priming, priming with plant extracts, nutrient priming, and chemical priming, and priming with plant growth regulators. The advanced techniques comprise seed priming through physical agents and nanoparticles (Hasanuzzaman, 2019).

\section{SEED PRIMING AND GERMINATION UNDER SALT STRESS}

Seed priming causes some changes in metabolic activities in the seeds for plumule emergence (Farooq et al., 2007). Seed priming techniques are considered to be very vital for enhancing seed germination under adverse effects like salinity. It has been recorded that priming treatment enhanced the seed germination and seedling growth of Cynanchum bungei Decne under salt stress (Zhang, 2015). Studies have shown increased germination percentage and seedling growth of Medicago sativa under salinity stress (Younesi \& Moradi, 2014). Seed priming with salicylic acid increases the salt tolerance in D. moldavica seedlings (Shairk-Abol-hasani \& Roshandel, 2019). Priming treatment has also enhanced salt stress Glycyrrhizauralensis seedlings (Zhang et al., 2015) and cauliflower (Wu et al., 2019). The role of seed priming could be considered catalytic, related to a series of physiological, biochemical, and molecular changes. Among them, the typical stress-tolerance response is by inducing the antioxidant system. The antioxidant enzymes act as a defense mechanism responsible for reducing reactive oxygen species (ROS). The accumulation of ROS leads to oxidative 
stress, eventually affecting the germination. The increased level of antioxidant enzymes has been reported through seed priming (Panuccio et al., 2018).

\section{Physiological, biochemical and molecular changes by seed priming}

Salinity causes osmotic, ion, and oxidative stresses during seed germination (Munns 2002; Ibrahim 2016). Under salinity, there is a decrease in the external osmotic potential, which results in less water uptake during the imbibition phase of germination. Seed priming increases osmolytes (e.g., sugar, amino acids, etc.), which helps in reducing the osmotic potential inside the seed. This reduced osmotic potential facilitates the absorption of water, speeding up the germination process under salinity stress.

Due to salinity excess influx of $\mathrm{Na}^{+}$results in $\mathrm{K}^{+}$ deficiency. This alters the protein and lipid composition of the membrane eventually affects the membrane permeability. Priming with polyamines has shown to retard membrane deterioration and also maintain the bilayer surface (Basra et al., 1994; Hussain et al., 2019)

Salt stress imposes a water deficit condition, leading to the formation of reactive oxygen species (ROS) such as Hydrogen peroxide, superoxide, and hydroxyl radical. These ROS can disrupt the metabolism and could also cause DNA damage affecting the cell cycle. Seed priming enhances the antioxidant defense system, which acts as ROS scavengers. Halo priming with sodium chloride in Vigna radiate alleviates the oxidative stress caused by salinity by enhancing the antioxidant defense system (Saha et al., 2010). Seed priming has shown to up-regulate many germinationrelated genes required for biochemical processes during seed germination in Chickpea seeds (Sharma et al., 2015).

\section{CONCLUSION}

Based on the previously reviewed literature, it is concluded that seed priming is a commercially used technique that is developed mainly to accelerate seed germination by minimizing the adverse effects of salinity. Seed priming is a practical and innovative approach for achieving rapid and uniform germination and stand establishment, which plays a significant role in higher productivity in crop plants, especially under unfavorable conditions. However, all priming methods may not lead to significant germination and uniform emergence; hence further in-depth studies on the physiology of seed are required for selecting specific priming methods, and the same could help us to identify the suitable molecular markers to optimize the priming treatment under salinity stress.

\section{REFERENCES}

[1]. Alves, R. D. C., Nicolau, M. C. M., Checchio, M. V., Sousa Junior, G. D. S., Oliveira, F. D. A. D., Prado, R. M., \& Gratão, P. L. (2020). Salt stress alleviation by seed priming with silicon in lettuce seedlings: an approach based on enhancing antioxidant responses. Bragantia, (AHEAD).

[2]. Anwar, A., Xianchang, Y. U., \& Yansu, L. I. (2020). Seed priming as a promising technique to improve growth, chlorophyll, photosynthesis and nutrient contents in cucumber seedlings. Notulae Botanicae Horti Agrobotanici ClujNapoca, 48(1), 116-127.

[3]. Basra, A. S., Singh, B., \& Malik, C. P. (1994). Priming-induced changes in polyamine levels in relation to vigor of aged onion seeds. Botanical Bulletin of Academia Sinica, 35(1), 19-23.

[4]. Bradford, K. J. (1986). Manipulation of seed water relations via osmotic priming to improve 
germination under stress conditions. HortScience (USA), 1105-1112.

[5]. Bradford, K. J. (1995). Water relations in seed germination. Seed development and germination, 1(13), 351-396.

[6]. Côme, D., \& Thévenot, C. (1982). Environmental control of embryo dormancy and germination. The physiology and biochemistry of seed development, dormancy and germination, 271-298.

[7]. Corbineau, F., \& Come, D. (2006). Priming: a technique for improving seed quality. Seed Testing International, 132, 38-40.

[8]. Farooq, M., Basra, S. M., \& Khan, M. B. (2007). Seed priming improves growth of nursery seedlings and yield of transplanted rice. Archives of Agronomy and Soil Science, 53(3), 315-326.

[9]. Hasanuzzaman, M., \& Fotopoulos, V. (2019). Priming and Pretreatment of Seeds and Seedlings. Springer Singapore

[10]. Ibrahim, E. A. (2016). Seed priming to alleviate salinity stress in germinating seeds. Journal of Plant Physiology, 192, 38-46

[11]. McDonald, M. B. (2000). Seed priming. Seed technology and its biological basis. Sheffield Academic Press, Sheffield, 287-325.

[12]. Munns, R. (2002). Comparative physiology of salt and water stress. Plant, cell \& environment, 25(2), 239-250.

[13]. Nawaz, J., Hussain, M., Jabbar, A., Nadeem, G. A., Sajid, M., Subtain, M. U., \& Shabbir, I. (2013). Seed priming a technique. International Journal of Agriculture and Crop Sciences, 6(20), 1373.

[14]. Panuccio, M. R., Chaabani, S., Roula, R., \& Muscolo, A. (2018). Bio-priming mitigates detrimental effects of salinity on maize improving antioxidant defense and preserving photosynthetic efficiency. Plant Physiology and Biochemistry, 132, 465-474.
[15]. Pawar, V. A., \& Laware, S. L. (2018). Seed Priming A Critical Review. Int J Sci Res Biol Sci [Internet], 31, 94-101.

[16]. Powell, A. A., \& Matthews, S. (1988). Seed treatments: developments and prospects. Outlook on Agriculture, 17(3), 97-103

[17]. Rhaman, M. S., Rauf, F., Tania, S. S., \& Khatun, M. (2020). Seed Priming Methods: Application in Field Crops and Future Perspectives. Asian Journal of Research in Crop Science, 8-19.

[18]. Saha, P., Chatterjee, P., \& Biswas, A. K. (2010). $\mathrm{NaCl}$ pretreatment alleviates salt stress by enhancement of antioxidant defense system and osmolyte accumulation in mungbean (Vigna radiata L. Wilczek). Indian journal of experimental biology, 48(6), 593-600.

[19]. Shaikh-Abol-hasani, F., \& Roshandel, P. (2019). Effects of priming with salicylic acid on germination traits of Dracocephalum moldavica L. under salinity stress. Plant Physiology, 10(1), 3035-3045.

[20]. Sharma, S. N., \& Maheshwari, A. (2015). Expression patterns of DNA repair genes associated with priming small and large chickpea (Cicer arietinum) seeds. Seed Science and Technology, 43(2), 250-261.

[21]. Suruthi, S., Sujatha, K., \& Menaka, C. (2019). Evaluation of different seed priming methods for improvement of seedling growth of barnyard millet (Echinochloa frumentacea L.) cv. MDU1. Electronic Journal of Plant Breeding, 10(2), 400-405.

[22]. Wu, L., Huo, W., Yao, D., \& Li, M. (2019). Effects of solid matrix priming (SMP) and salt stress on broccoli and cauliflower seed germination and early seedling growth. Scientia Horticulturae, 255, 161-168.

[23]. Younesi, O., \& Moradi, A. (2014). Effect of priming of seeds of Medicago sativa 'bami'with gibberellic acid on germination, seedlings growth and antioxidant enzymes activity under 
salinity stress. Journal of Horticultural Research, 22(2), 167-174.

[24]. Zhang, H. (2015). Nitric oxide alleviates the inhibition of salinity stress on seed germination and seedling growth of Cynanchum bungei Decne (Asclepiadaceae). HortScience, 50(1), 119-122.

[25]. Zhang, X. H., Zhou, D., Cui, J. J., Ma, H. L., Lang, D. Y., Wu, X. L., . \& Li, M. (2015). Effect of Silicon on seed germination and the physiological characteristics of Glycyrrhizauralensis under different levels of salinity. The Journal of Horticultural Science and Biotechnology, 90(4), 439-443.

\section{Cite this article as :}

Sandhya R Verma, Dr. Hitesh A Solanki, "Alleviating Salinity Stress During Seed Germinating by Priming Techniques : A Review", International Journal of Scientific Research in Science and Technology (IJSRST), Online ISSN : 2395-602X, Print ISSN : 23956011, Volume 8 Issue 2, pp. 198-202, March-April 2021. Available at doi $\quad$ : https://doi.org/10.32628/IJSRST218225 Journal URL : https://ijsrst.com/IJSRST218225 